\title{
Peering through the gaps in music history
}

Joseph W. Mason

The history of medieval music has generally been woven together with reference to large, lavish and seemingly complete books of notated music. Sources such as the Montpellier Codex, the interpolated Roman de Fauvel or the Squarcialupi Codex are major repositories for medieval music, and the information they provide has been stitched together to construct the narratives of music history with which we are familiar. Small, incomplete or fragmentary sources are, by contrast, normally pushed to the margins (sometimes literally) of historical narratives. The musicological tendency to cast some sources as central and others as peripheral has been noted by several scholars: Leo Treitler, for example, describes the urgent need in the 1970s to address this historiographical problem (With voice and pen (Oxford, 2003), p.84). Two recent symposia have continued to challenge mono-linear histories of medieval music by assessing sources traditionally pushed to the historiographical periphery.

The first of these, 'MS 389 and its Songs: an Interdisciplinary Workshop', was held at the University of Bern in December 2017. Scholars from the UK, continental Europe and the USA gathered to discuss the late 13th-century trouvère chansonnier, Ms.389, held in Bern's Bürgerbibliothek. The workshop was organized by Henry Hope in conjunction with the publication of a digital facsimile of the chansonnier at ecodices.ch, the Virtual Manuscript Library of Switzerland. Papers were presented from the perspectives of philology (Paola Moreno), art history (Alison Stones), literature (Daniel E. O'Sullivan) and musicology (Robert Lug, Elizabeth Eva Leach, Matthew P. Thomson, Henry Hope, Joseph W. Mason); the increasing richness of discussion and deepening understanding of the Bern chansonnier over the course of the two-day workshop was testament to the fruitfulness of interdisciplinary collaboration. Papers from the workshop will be published in a forthcoming issue of the Schweizer Jahrbuch für Musikwissenschaft.

Ms.389 is an unusual songbook. The codex's 522 songs are organized alphabetically by the first letter of their first line, and each letter section opens with a devotional song (mostly in praise of the Virgin Mary); both of these features are unusual for a trouvère chansonnier. The source's eastern provenance (likely Metz) 
and incomplete state have led to its scholarly neglect: music staves are ruled throughout the codex, but no music notation was ever entered. Moreno, Stones, Lug and Leach focused on how the codex was created, challenging the scribal stemmatics that were proposed by Eduard Schwan in 1886. The other four papers considered the songs of Ms.389, relating them to the wider practices of trouvère song (O'Sullivan and Mason), motets (Thomson) and Minnesang (Hope). Despite the lack of music notation in the chansonnier, we can learn much about the songs of Ms.389, especially when songs are transmitted in other sources with music notation, or when contrafacts are taken into consideration. This was beautifully demonstrated at the conference concert, in which songs from Ms.389 (with melodies supplied from other chansonniers) were performed to great effect by Marc Lewon and students from the Schola Cantorum Basiliensis.

A second symposium, 'Disiecta Membra Musicae: the Study of Medieval Music Manuscript Fragments ca. 800-1500', took place at Magdalen College, Oxford, in March 2018. A series of papers were delivered by an international coterie of medieval musicologists (plus the director of the e-codices.ch Virtual Manuscript Library) who between them specialized in over eight centuries of music writing across the length and breadth of the Catholic West. Organized by Giovanni Varelli, the symposium was held in conjunction with an exhibition of music manuscript fragments in the Magdalen collections. These fragments have been recovered from other volumes, in which they had been used as binding materials-mostly as pastedowns, flyleaves or covers. Many of the fragments on display were from liturgical sources of plainsong, of English provenance and ranging in date from the late $10^{\text {th }}$ to the $16^{\text {th }}$ century. There were two exceptions: two leaves of lute tablature from late 16th- or early 17th-century England; and several leaves containing 15th-century polyphonic settings of Mass movements, which may have belonged to a lost royal choirbook not dissimilar to the famous Old Hall Manuscript.

Margaret Bent opened the symposium with her keynote address on the history of music manuscript fragments. In a virtuosic and whistle-stop tour across the centuries, Bent reminded us that music manuscripts were destroyed for a number of reasons. Like many other kinds of books, manuscripts containing music notation were vulnerable to acts of God, even more so when in ephemeral form, such as a single leaf. Musical works and the performance culture to which they related could go quickly 
out of fashion; as a result, the parchment of music books could be worth more than the music that they transmitted. 'Biblioclasm'-the destruction of books for ideological reasons - also played its part in the fragmentation of musical sources, as did the acts of later collectors. The reasons for which music books were destroyed and reused was a recurring theme in discussion throughout the symposium.

A number of papers examined music fragments that pose challenges to established narratives of music history. Susan Rankin showed that two fragments of early chant from St Gall change what we know about chants for processions before the inception of the processional as a book in its own right. Daniele Sabaino's reconstruction of a song notated on the verso side of a late 12th-century charter challenged the notion of a divorce between poetry and music in 13th-century Italy. In her paper on song fragments in English sources, Helen Deeming opened questions as to what a fragment is. Examining not only small sources of English song such as miscellanies or individual leaves, she also demonstrated the use of refrains, a kind of melodic fragment, in several unexpected contexts, including in sermons. David Catalunya showed the extant of Ars Antiqua sources in Spain, proposing new connections between the royal courts of Castile and Paris.

Three papers took a broad approach, examining the fragments that survive in geographical areas that have been treated as peripheral to music history: Scandinavia (Sean Dunnahoe), Slovenia (Jurij Snoj) and Central Europe (Paweł Gancarczyk). Each scholar grappled with the difficulty of dealing with large collections of fragments, given that every fragment has its own complicated history of production, destruction and reuse. Other papers considered the fragments gathered by individual collectors. Christian Leitmeir presented the idiosyncratic curatorial habits of Amplonius de Berka, whose collection contains more that relates to music than one might expect. Karl Kügle argued that the destruction and reuse of a music source could be an aesthetic choice: in a book of sermons now held in Koblenz, the flyleaves, which transmit 14th-century motets, were selected to complement the contents of the new book. Reinhard Strohm asked whether a collection of over 30 musical items in a number of different 15thcentury hands was gathered for use by an organist. Each of these papers showed, to a greater or lesser extent, what happens when the potential utility of a music book changes. 
Digital approaches to the growing study of fragments—or 'fragmentology'were the third strand of discussion. In his discussion of fragmentary saints' Offices from southern Germany, David Hiley demonstrated the usefulness of a resource such as the Cantus database (http://cantusindex.org/). Databases for fragments such as Fragmentarium (www.fragmentarium.unifr.ch), which Christoph Flüeler presented, or Fragmenta Manuscriptorum Musicalium Hungariae Mediaevalis, discussed by Zsuzsa Czagány, will doubtless yield much fruit in future scholarship. Digital advances also provide opportunities for restoration and public impact, as we saw in the 'magic' of Julia Craig-McFeely's work on the Sadler Partbooks or in Raquel Rojo Carillo's presentation of expo.neumes.org.uk, an online platform that introduces and explains Old Hispanic Chant.

Although scholars of medieval music will always be reliant on lavish and complete sources of medieval music - a point made eloquently by Nicolas Bell in his closing remarks to the symposium - the study of music fragments can add much to medieval musicology. At the very least, fragments of music manuscripts are a reminder of just how much notated music has been lost, and how exceptional complete sources of medieval music are. Both symposia, meticulously organized by Henry Hope and Giovanni Varelli, have shown that the historical information gleaned from incomplete sources of music has the potential to enrich the field of study in important and unpredictable ways. This bodes well for the future: more and more fragments of medieval music are brought to light each year, and digital platforms for medieval music will enable scholars to make new connections between musical sources across a wide geographical span. If the tapestry of early music history is unavoidably patchy at the moment, future discoveries promise to fill in some of the gaps in new, exciting and challenging ways. 